\title{
BUDDHIST MYSTICISM AND PHILOSOPHY
}

\section{Book Title:}

Turning-points in

Buddhist mysticism and

philosophy

Book Cover:

No image available

\section{Author:}

Jacobus S. Kruger

ISBN:

978-0-6203-9731-5

\section{Publisher:}

Aurora Press, New Mexico, pp. 192, cost unknown

Review Title:

Buddhist mysticism and

philosophy

\section{Reviewer:}

Ignatius (Naas) W. Ferreira ${ }^{1}$

\section{Affiliation: \\ ${ }^{1}$ Department of Practical \\ Theology, University of \\ Pretoria, South Africa}

email:

naasf@mweb.co.za

Postal address:

PO Box 12402, Elspark

1418, South Africa

How to cite this book review:

Ferreira, I.W., 2010,

'Buddhist mysticism and

philosophy', HTS Teologiese

Studies/Theological Studies

66(1), Art. \#993, 1 page.

DOI: 10.4102/hts.v66i1.993

This review is available

at:

http://www.hts.org.za
The contemplative traditions of all the mayor religions have struggled with the relationship between the true Self and the ego-self and with the interior and exterior of Reality. Most wisdom teachings, at one stage or the other, have rejected the ego, thoughts or personality as a case of mistaken identity and the 'world' as an illusion. The True Self is the one who witnesses or observes everything and who cannot be identified with the observed.

The Bhagavad Gita, the revered Hindu Scripture that is almost 2500 years old, is a metaphorical account of the conversation between Lord Krishna and Arjuna about the inner journey to the True Self. Buddhism stemmed from Hinduism and can largely be attributed to the efforts of a young noble man, Siddhartha Gautama, who had lived between 566 to about 486 BCE. For six years he sought to understand the forms of life and finally attained the full state of nirvana, a state Kruger refers to as the 'end of delusion'. After this experience he became the Buddha, or the Enlightened One. He shared his experience with his followers and explained how they, too, could experience full Enlightenment. For two and a half millennia his followers strove to articulate the philosophical ramifications of attaining Enlightenment and to express its implications in organisation, ritual, works of art and culture in general. Jesus, on the other hand, was a mystic who proclaimed that the Kingdom of Heaven is inside everyone and taught that he was the True Self, as 'before Abraham was, I am'. However, his followers resisted this route and turned the mystical teachings and the mystic Jesus into mythology. Christianity rejected Gnostics who tried to stay true to Jesus' teachings. Even the Christian mystics of the Middle Ages could not prevent the change from the mythological to the mystical.

The same did not happen in Buddhism. The Buddha's teachings were aimed at Enlightenment with no speculation in terms of what 'God' or Emptiness might be. At the heart of Buddhism lie the 'Four Noble Truths': the human condition is about suffering. Humans suffer because they crave or want something. To end suffering, humans must stop craving and in order to achieve that, they need to comply with the eight conditions of seeing things rightly, having the right commitment, speaking rightly, acting rightly, living rightly, making the right effort, being rightfully-minded and achieving states of being rightfully tranquil.

Kruger identifies four major turning-points or schools, also discussing one or two representative figures for each in order to demonstrate how Buddhist mysticism and philosophy have developed. The first turning point was the Hinayana Abhidharma; then came the Nagarjuna and the Madhyamika school; followed by the Vasubandhu and the Yogacara school; with Fa-Tsang and the Hua-Yen being the last turning point or school. Kruger's (2008) central interest is twofold:

What is the mystical kernel of Buddhism and secondly, how was this unique sense of things treated in Buddhist philosophy as it attempted to explain and serve it? The key questions leading our interest were:

- What, according to the four schools, the nature of the human being, is cosmos and ultimacy and what is the relationship between them?

- What is the nature and what are the possibilities of human knowledge and understanding?

- What is the nature and origin of evil and suffering?

- What does the transformation of the human person entail?

(Kruger 2008:137, 138)

Turning-points in Buddhist mysticism and philosophy is not easy reading matter for a non-Buddhist or a novice. Not only does the reader have to cope with Sanskrit words, but the mind has to grasp and assimilate the concepts. Even the sentence and paragraph structures are daunting at times. There is no doubt that Kruger has reached the mystical levels of consciousness and knows his subject in depth. But the publisher should have made a greater effort to present the development of schools of Buddhism in India graphically (p. 30). Turning-points in Buddhist mysticism and philosophy is an excellent example of what mysticism could have been in enlightened Christianity and as the quote below suggests, Jesus could very well have said the following:

Thus there is no being,

Likewise no cessation.

Therefore beings, each and every one,

Are unborn and are never ceasing.
(C) 2010. The Authors. Licensee: OpenJournals Publishing. This work is licensed under the Creative Commons Attribution License. 